\title{
Dendrogeomorphological analysis of the Sawicki Landslide in the Beskid Niski Mountains (S Poland)
}

\author{
Marek KRAPIEC ${ }^{1}$, Natalia NAWROCKA ${ }^{1}$, Włodzimierz MARGIELEWSKI ${ }^{2}$ \\ and Elżbieta SZYCHOWSKA-KRAZPIEC ${ }^{1, *}$ \\ 1 AGH University of Science and Technology, Al. A. Mickiewicza 30, 30-059 Kraków, Poland \\ 2 Institute of Nature Conservation, Polish Academy of Sciences, Al. A. Mickiewicza 33, 31-120 Kraków, Poland
}

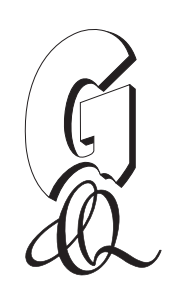

Krapiec, M., Nawrocka, N., Margielewski, W., Szychowska-Krapiec, E., 2019. Dendrogeomorphological analysis of the Sawicki Landslide in the Beskid Niski Mountains (S Poland). Geological Quarterly, 63 (4): 801-810, doi: 10.7306/gq.1506

Associate Editor: Wojciech Granoszewski

We applied dendrochronological analysis to study an extensive ( $2.5 \mathrm{~km}$ long) complex-type landslide in the Beskid Niski Mountains (Polish Flysch Carpathians), which was rejuvenated in historical time (the earliest transformation occurred in 1913). We used three complementary methods (dating of eccentricity of annual growth rings, eccentricity indices, and analysis of reaction wood), based on seven species of deciduous and coniferous trees. A total of 204 trees were sampled and 408 cores collected using a Pressler increment borer. Based on the dendrochronological analysis, the activity of various parts of the landslide in the past century is presented, which appears to have been diverse and influenced mostly by precipitation. The upper part of the landslide was active from the 1920s until the 1940s. In the middle section of the landslide, intensifications of gravitational movement were repeatedly recorded after intense rainfalls throughout the entirety of the last century. The highest landslide activity was dendrochronologically detected in the 1980s and 1990s. Increasing landslide activity during so-called "dry years" may have been related to quick drying of the bedrock, resulting in changes in rock strength parameters. Our results indicate significant susceptibility of this particular slope-valley geosystem in response to even slight hydrogeological changes (including dryness), which can trigger ground movement.

Key words: dendrogeomorphological analysis, complementary method, complex-type landslide, Polish Flysch Carpathians, southern Poland.

\section{INTRODUCTION}

Annual tree rings provide various data regarding environmental conditions and changes. Dendrochronological analysis is used to reconstruct sequences of various geological (Baillie, 2008; Bekker, 2010), geomorphological (McAuliffe et al., 2006; Bollschweiler et al., 2009; Stoffel et al., 2012) and hydrological processes (StGeorge and Nielsen, 2002; Stoffel and Wilford, 2012). Tree rings also record anthropogenic pollution (Oleksyn, 1988; Malik et al., 2012). Dendrochronological analysis, as well as isotopic analysis of subfossil trees, is used to reconstruct palaeoenvironmental (mainly palaeoclimatic) changes (Pazdur et al., 2005; Edvardsson et al., 2012; Krapiec et al., 2016). Moreover, living trees record evidence of mass movement activities (i.e. ground destabilization) in their annual rings (Alestalo, 1971; Shroder, 1980; Braam et al., 1987a, b; Krapiec and Margielewski, 1991, 2000; Stoffel et al., 2013). Application of dendrochronological methods for the reconstruction of past ac-

* Corresponding author, e-mail: szycha@geol.agh.edu.pl Received: Frebruary 8, 2019; accepted: September 25, 2019; first published online: December 20, 2019 tivity of mass movement enables determining the distribution of landslide movements over time, and reconstructing landslide history (Braam et al., 1987a, b; Krapiec and Margielewski, 1991, 2000; Corominas and Moya, 1999; Stefanini, 2004; Stoffel et al., 2013; Silhan and Stoffel, 2015). The dendrogeomorphological studies aimed at identification of climatic conditions affecting the development and activity phases of landslides, concerning also numerous landslides in the Beskidy Mountains, and data for a large part of the Polish Western Carpathians have been collected (Krapiec and Margielewski, 1991, 2000; Krapiec and Rączkowski, 2005; Krapiec et al., 2008; Kiszka, 2016).

Dendrogeomorphological analysis presented in the paper was carried out on an active landslide $(\sim 2.5 \mathrm{~km}$ long $)$ called the Sawicki Landslide, situated in the Beskid Niski Mountains within the Flysch Carpathians. This landslide has been already analysed using one of the dendrogeomorphological methods, namely the deconcentricity method (Krapiec and Rączkowski, 2005; Krapiec et al., 2008; Nawrocka, 2013; Kiszka, 2016). The aim of our study is to reconstruct the history of Sawicki Landslide activity, using complex three complementary methods: dating of eccentricity of annual growth rings, eccentricity indices, and analysis of reaction wood, based on seven species of deciduous and coniferous trees. 


\section{STUDY AREA}

The study was carried out on a vast active complex-type landslide called the "Sawicki Landslide" after its first investigator, Ludomir Sawicki. The investigation locality is presented in Figure 1. Several factors were considered to chose of the sampling strategy to meet the research objects. They include the presence of distinct elements of the landslide relief, traces of secondary landslide motions, as well as the fact that the vast landslide area is forested by a multi-species stand of trees of sufficient age to provide information regarding gravitational movements over at least the last 100 years.

The landslide is located in the Polish Flysch Carpathians, in an area of three tectonic units (Magura, Dukla, Silesian) overthrust to the north-east. All three units consist of sandstone-shale flysch that was deposited from the Late Cretaceous to the Early Miocene (Świdziński, 1973; Kopciowski et al., 1997, 2014; Jankowski, 2007, 2015). A large part of study area is covered by Quaternary sediments. Flysch massifs, occurring in the study area, are strongly folded and faulted (Jankowski, 2015). Tectonic discontinuities, as well as chaotic complexes (e.g.,
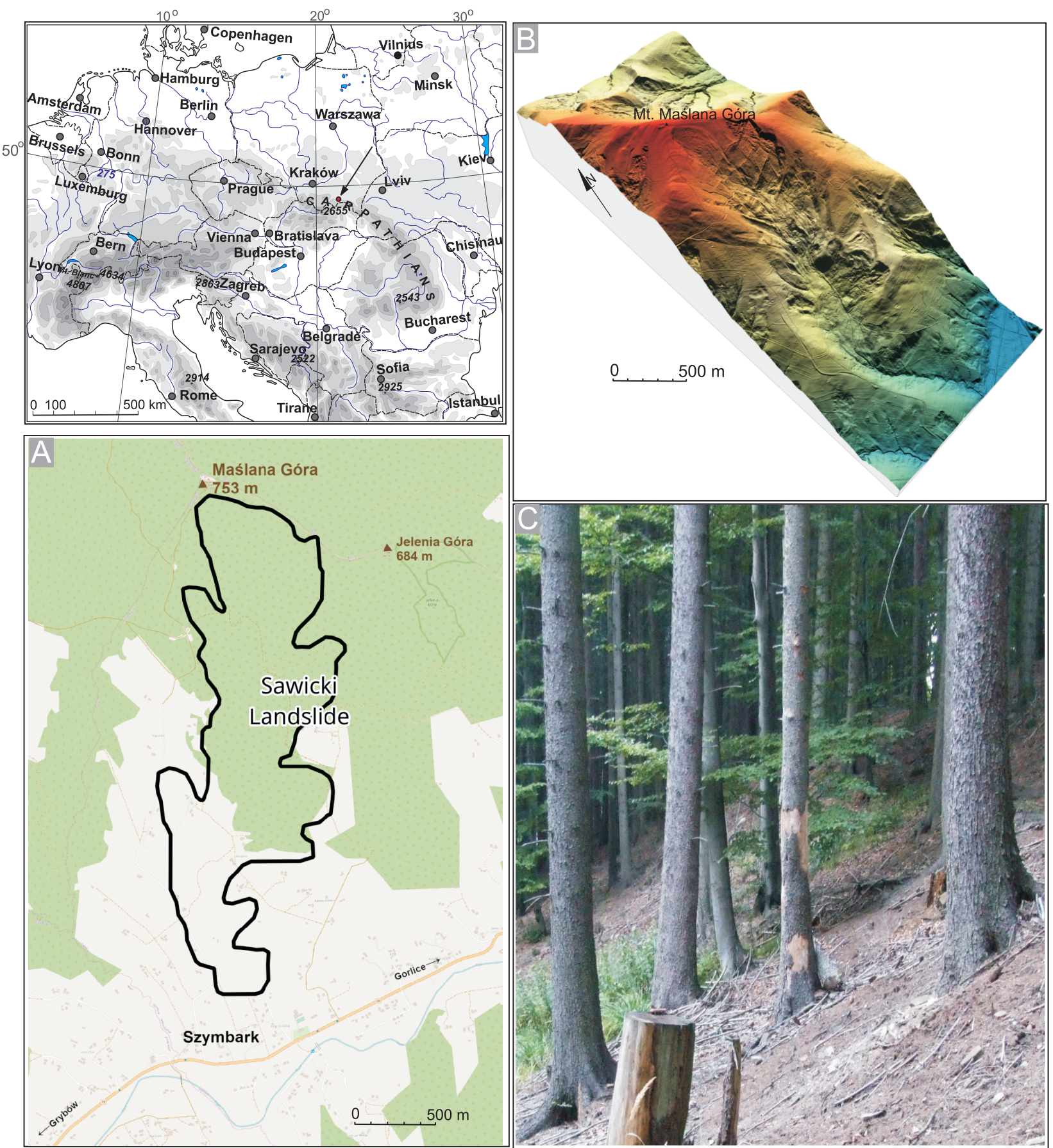

Fig. 1. Location of the Sawicki landslide area: A - landslide location; B - landslide on the digital (LIDAR) terrain model; $\mathrm{C}$ - trees with deformed trunks overgrowing the landslide area 
olistoliths, tectonic mélanges) occurring in the Beskid Niski Mountains (Jankowski, 2007), are favourable for mass movement formation in these parts of the Outer Carpathians. Relief is generally related to the geological structures, including differences in bedrock strength (Starkel, 1960), position of the flysch massifs in the structure of the Carpathian orogen (Jankowski and Margielewski, 2014), and the disjunctive tectonics determined by the occurrence of numerous faults, or even tectonic mélange zones, often used by river valleys (Jankowski, 2007). The study area is conspicuous by the occurrence of relief elements typical for both the Carpathian foothills and Beskidy Mountains (Kotarba, 1986). The typical relief type for the Beskids consists of inversely carved ridges that formed within syncline or monocline structures, composed mostly of thick-bedded weathering-resistant Magura sandstones. The ridges in the foothill zones are more fragmented, and the hills are generally gentle with broad and even plateau tops and steep slopes (Starkel, 1960; Kotarba, 1986).

The Beskid Niski Mountains is an area of ubiquitous landslides that strongly transform the relief. In fact, the effects of mass movement in this mountain range are so well manifested that it is the area where the term "landslide-type" relief was first introduced (Starkel, 1960). In this area, slopes are heavily changed by mass movement, and landslides locally cover up to $30 \%$ of their surface (Kotarba, 1986; Długosz, 2011; Mrozek, 2013), are formed also currently (Łajczak et al., 2014). The most common are small landslides (usually $<10$ ha). Large areas are occupied by landslides that formed by the overlapping and merging of smaller forms. In terms of the character of gravitational displacements and type of material displaced, these are mostly rotational, translational and compound landslides, encompassing both the bedrock and slope covers (Zabuski et al., 2009). The variation in bedrock lithology and strength (e.g., rigid thick-bedded sandstones overlying susceptible shales) and tectonic conditions (e.g., strongly jointed rock massifs cut by numerous faults occasionally forming tectonic mélange - Jankowski, 2007, 2015) are conducive to the frequent occurrence of mass movement (Bober, 1984; Zabuski et al., 2009). Intensification of the mass movements in this part of the Beskid Niski Mountains took place in the Early and Late Holocene (Gil et al., 1974; Wójcik et al., 2006), when landslides formed, developed and transformed in cyclical periods of climate humidity, for which extreme or long-term precipitation events were recorded (Gil et al., 1974; Alexandrowicz, 1996; Starkel, 1997; Margielewski, 2006, 2018; Margielewski et al., 2010).

The landslide analysed in this study is located north-west of Szymbark (Gorlice county) on the southern slopes of Mt. Maślana Góra (753 m a.s.I.) (Fig. 1A). It is an old, large complex-type landslide, dated to the Middle Holocene (Sawicki, 1917; Wójcik et al., 2006; Rączkowski, 2007b; Rączkowski and Zabuski, 2008). The landslide has a total surface area of 151.1 ha and a length and width of 2846 and $500 \mathrm{~m}$, respectively (Fig. 1A, B). It extends at the elevation between 345 to $725 \mathrm{~m}$ a.s.l., stretching over almost the entire Szklarka Creek catchment.

The upper part of the Sawicki Landslide was formed in the thick-bedded Magura sandstones of the Maślana Góra Syncline, whereas the middle and lower parts were formed in the Ciężkowice and Mutne sandstones (intercalated by variegated shales) of the Szymbark Slice (Kopciowski et al., 1997, 2014). The lowest part of the landslide is formed in the Inoceramian Beds.

The main scarp of the landslide is steep and almost $30 \mathrm{~m}$ high. Multiple secondary scarps, up to several metres in height, formed within the landslide body below the main one during secondary movements. The thickness of the colluvium is estimated to be $\sim 30 \mathrm{~m}$ (Rączkowski, 2007b). The colluvium consists of boulders, clays with debris, blocks, and detrital material (Fig. 1B; Rączkowski, 2007b). In the middle of the landslide, damming of the creek by the colluvial material has resulted in the formation of a small lake. The landslide is periodically active, particularly under wet hydrometeorological conditions. It was rejuvenated in 1784 and completely remodelled in 1913 (Sawicki, 1917; Krapiec et al., 2008).

\section{MATERIALS AND METHODS}

\section{SAMPLING AND MEASUREMENTS}

This study concerns living trees growing on the Sawicki Landslide, as well as stable areas in the close vicinity of the landslide. The sampling, conducted in two research periods in 2003 and 2011, resulted in the collection of 408 samples (cores) from 204 trees using a Pressler increment borer. The trees selected for sampling were visually assessed as healthy, dominating and devoid of visible canopy damages or loss of the assimilatory apparatus. The exact location of the individuals was determined using GPS.

A total of 174 trees of various species (both coniferous and deciduous, ring porous and diffuse porous) were sampled from the landslide area (Table 1). The core samples were collected from trees exhibiting visible changes in the morphology of their trunks, such that they were deformed and rotated by self-adjustment to a vertical position (Fig. 1C). For each tree in the dendrogeomorphological study, two samples were taken from both the slope-facing (upslope) and opposite (downslope) sides of the trunk at its maximum bend.

Samples were also taken from trees growing on stable slopes without any traces of gravitational movements. Two cores were acquired from each of 10 trees of the following species: fir (Abies alba Mill.), European larch (Larix decidua Mill.), and Scots pine (Pinus sylvestris L.), yielding a total of 60 samples. These samples have been used in a comparative study, providing material to construct local chronologies. Sample preparation and analysis were carried out in the Dendrochronological Laboratory of the AGH - University of Science and Technology in Kraków (Poland) using the DENDROLAB measurement set. Measurements of the annual tree-ring width were made with $0.01 \mathrm{~mm}$ accuracy on a properly crafted cross-section (i.e. transversal surface) from the core to the

\section{Table 1}

Tree species sampled on the Sawicki Landslide

\begin{tabular}{|l|c|}
\hline & Number of trees \\
\hline Silver fir (Abies alba Mill.) & 99 \\
\hline European larch (Larix decidua Mill.) & 45 \\
\hline Scots Pine (Pinus sylvestris L.) & 33 \\
\hline $\begin{array}{l}\text { Sycamore maple } \\
\text { (Acer pseudoplatanus L.) }\end{array}$ & 15 \\
\hline Common Beech (Fagus sylvatica L.) & 5 \\
\hline Norway Spruce (Picea abies Karst) & 6 \\
\hline Scots elm (Ulmus glabra Huds.) & 1 \\
\hline TOTAL & 204 trees (408 cores) \\
\hline
\end{tabular}


youngest ring. The measured sequences were processed using TREE-RINGS (Krawczyk and Krapiec, 1995) and QUERCUS (Walanus, 2005) program packages. Trees growing on landslides are rarely older than 100 years. The longest sequence consisted of 137 tree rings and dated back to the year 1875 .

\section{DENDROGEOMORPHOLOGICAL ANALYSIS}

In the case of possibility of determining the period of gravitational bedrock displacements, the dendrogeomorphological analysis was carried out using three different methods.

Based on the eccentricity of annual increments, we used:

- analysis of pairs of tree-ring patterns of trees growing on landslide areas (Braam et al., 1987a, b; Krapiec and Margielewski, 1991, 2000),

- reaction wood analysis (Alestalo, 1971; Shroder, 1980),

- eccentricity index evaluation (Malik and Wistuba, 2012).

Reference chronologies were also constructed for conifers.

Dendrochronological curves (dendrograms) were produced from the measured sequences of annual increments of trees growing on the landslide area. The dendrochronological curves for individual trees are presented in pairs, representing upslope and downslope sides of the trunks. The eccentricity of the annual growths on the dendrogeomorphological curves is expressed as a long-term divergence of dendrograms, when the width of the ring on one side of the trunk suddenly increases or decreases compared with the opposite side (Braam et al., 1987b; Krapiec and Margielewski, 1991; Fig. 2). A characteristic distribution pattern of the dendrochronological curves, connected with their rapid divergence caused by a change in the ratio of annual growth widths in the upslope and downslope parts of the trunk, is considered an indicator of mass movements, which allows estimation of their time range (Shroder, 1980; Corominas and Moya, 1999; Krapiec and Margielewski, 2000). The most important information for dating landslide events was the initial stage of this process. Divergence periods, as well as the years when reaction wood was formed, were identified for each pair of curves. Clear events (i.e. sharp divergence of dendrograms) were linked to the onset of the mass movement that caused deformation to the tree trunks, whereas reaction wood was helpful to identify episodes of landslide movement (Krapiec et al., 2008). Spatial analysis of the acquired results allowed tracking of the changes in the intensity of the landslide processes across various parts of the landslide. The results are the basis for the compilation of landslide activity maps for individual years or periods of several years.

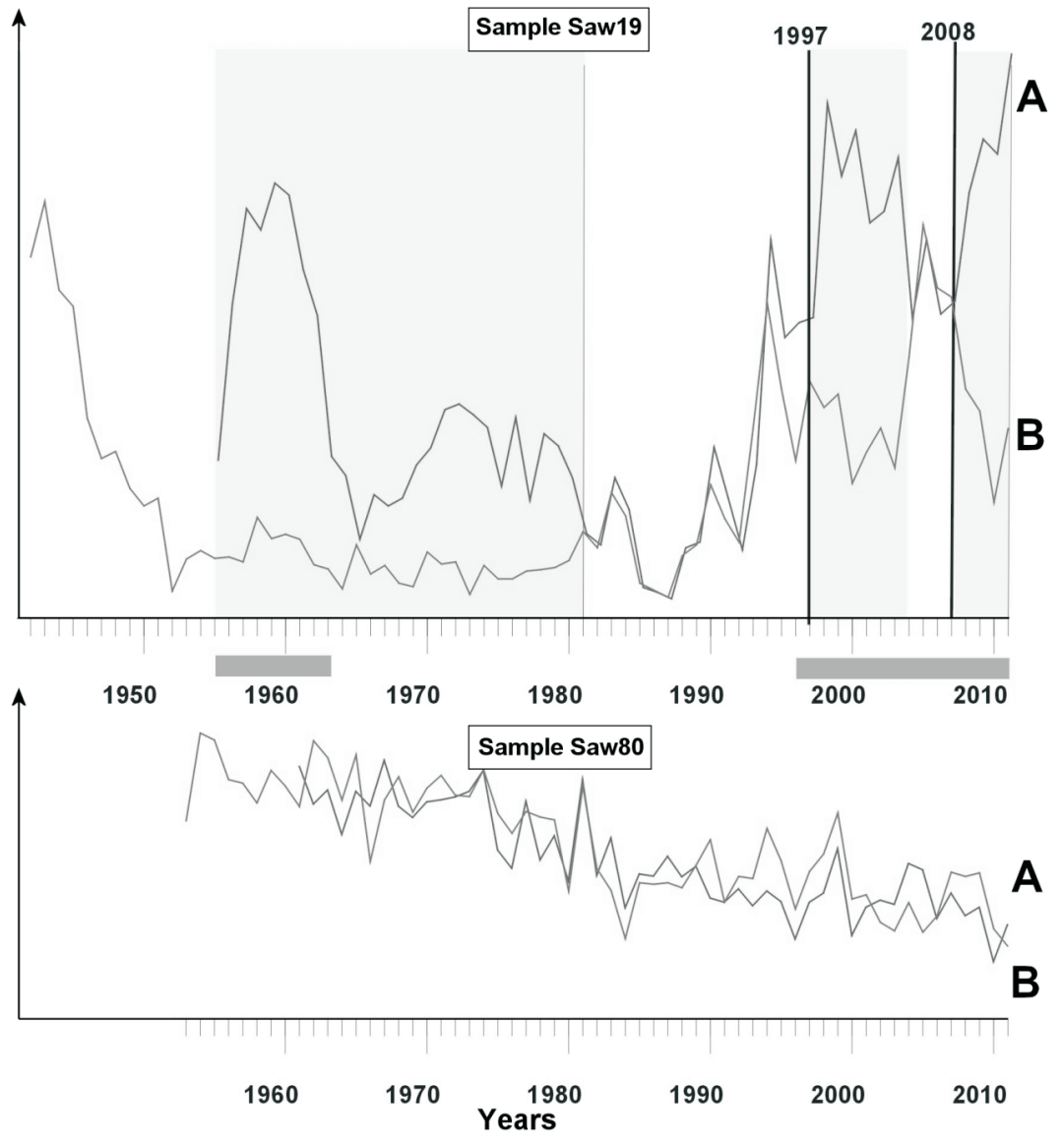

Fig. 2. An example of dendrogeomorphological analysis based on samples taken from fir trees growing on the landslide area (Saw19) and on the stable area (Saw80)

The periods in which the dendrograms from the downslope (A) and upslope (B) part of trunk diverged are marked in grey; the extent of reaction wood is marked on the axis 
Within the framework of research carried out on the Sawicki Landslide in 2011, the method of tree-ring eccentricity index evaluation was used according to the formulas proposed by Wistuba and Malik (2011; see also Malik and Wistuba, 2012):

$$
\begin{gathered}
E x=U x-D x \\
\text { Eix }=(E x / D x) \times 100 \% \text { (if } D>U) \\
\text { Eix }=(E x / U x) \times 100 \% \text { (if } D<U) \\
v E i x=\text { Eix-Eix-1 }
\end{gathered}
$$

where: $\mathrm{E}$ - eccentricity [mm], Ei - eccentricity index [\%], vEi - yearly variation of the eccentricity index [\%], $U$ - width of tree ring on the upslope side of tree trunk [mm], D - width of tree ring on the downslope side of tree trunk [mm], $x$ - year/annual tree ring.

The eccentricity in millimetres and the eccentricity index percentiles were calculated based on measured sequences of annual growth width from both sides of the trunks (i.e. downslope and upslope). These indicators were determined both for each tree as a whole and separately for each annual growth ring. The year-to-year variability of eccentricity index indicators was used for dating the beginning of ground movement. This was calculated as the difference between index values in a given year compared with the previous one. The threshold values for dating periods of gravitational movement were determined based on results for the trees growing in stable terrains as an arithmetic average of the deconcentricity index.

\section{RESULTS}

LOCAL CHRONOLOGIES

FOR CONIFEROUS TREES SPECIES

Based on 60 annual growth sequences, obtained from 30 trees of the three coniferous species growing in areas unaffected by deep mass movements, samples with the highest similarity were chosen for further analysis. Dendrograms constructed for the selected trees are devoid of disorders (e.g., growth depressions). Identification of the best fitting individual sequences, the maximum values of their calculated correlation coefficients, and the visual resemblance of curves were taken into account. In this way, at least 10 sequences were selected for each species. Dendrochronological patterns were constructed, after being averaged, as the local and standard chronologies (Szychowska-Krapiec, 2010), which primarily reflect a climatic impact. Further analyses accounted for divergence of the dendrochronological curves and tree-ring eccentricities, which are diagnostic of the mass movements, and were included in a definite trend associated with climatic or anthropogenic factors (Krapiec and Margielewski, 2000).

\section{COMPARISON OF PAIRS OF DENDROCHRONOLOGICAL CURVES WITH REACTION WOOD ANALYSES}

A pair of dendrograms was drawn for each tree growing in the landslide area, and the extent of reaction wood occurrence was recorded. For example, three periods of dispersion curves
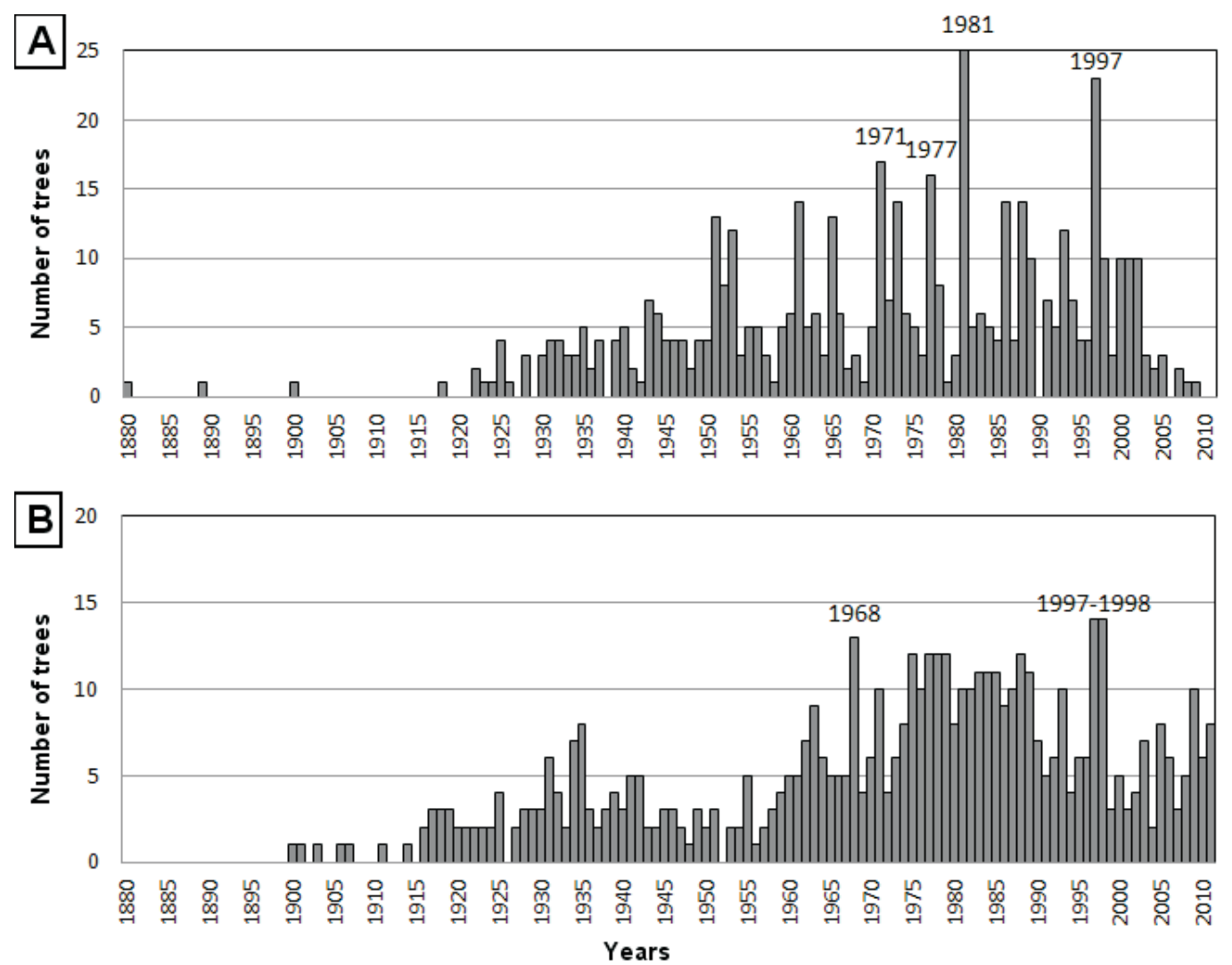

Fig. 3. Distribution of the landslide activity signals generated by: A - initial year of a long-term divergence of dendrograms; B - eccentricity index evaluation method for each year 
were identified for fir growing on colluvium in the middle of the landslide (tree No. Saw19 - see Fig. 2). As the core sampled from the upslope side of the trunk was incomplete, the beginning of the first phase of gravitational ground movement could not be precisely identified. A distinct zone of reaction wood could be observed in the period 1955-1963. High eccentricity of annual growth and, in turn, significant divergence of dendrograms for the slope-facing and opposite sides of the trunk lasted until 1980. Another reaction wood zone began to form in 1997 and continued until the youngest ring of the sampled core was collected in 2011. Within this zone, the years in which divergence of the dendrochronological curves began (i.e. 1997 and 2008) could be considered diagnostic for ground movement. The interpretation presented above was applied to all samples analyses from the investigated landslide. Analysis of dendrochronological curves also demonstrates that the graphs for the landslide slope and stable areas are significantly different. Graphs for the reference trees are devoid of considerable periods of divergence from the dendrochronological curves. Moreover, in most cases, there was no reaction wood. The curves have similar and approximately parallel courses, in which the periods of single years with very low eccentricity alternate (Fig. 2).

A summary of the initial diagnostic periods (i.e. years for which the dendrochronological curves of the opposite radii drifted apart and reaction wood occurred), that indicate initial displacement dates, was used to illustrate the movement intensity in individual years (Fig. 3A). The graph clearly marks the years for which many trees responded to ground movement.

Less data are available for the period prior to 1930 , which is probably the reason for the small number of trees showing a reaction in the summary for those years. The oldest sampled tree with a reaction within annual growth was dated to 1889. Figure $3 \mathrm{~A}$ shows that the maximum number of tree reactions, visible as a characteristic dendrogram divergence from the opposite parts of the trunk, took place in 1981 (25 trees; $14 \%$ of those growing on the landslide) and 1997 (23 trees; 13\%). A large number of trees responsive to ground movement was also observed for 1971 (17 trees; 10\%), 1977 (16 trees; 9\%), 1961, 1973, 1986, 1988 (14 trees; 8\%), 1951, 1965 (13 trees; 7\%), 1953, 1993 (12 trees; 7\%), 1989, 1998, and 2000 to 2002 (10 trees; $6 \%$ ). After 2000 , the number of responding trees is significantly smaller, but the landslide body is still not completely stable (Fig. 3A, B). In 2010-2011, none of the surveyed trees recorded an initiation of the reaction (i.e. divergence of curves). However, the annual ring eccentricity of numerous trees could be observed until the final analysis year (2011), which indicates that these trees did not return to the equilibrium state.

The vast majority of reaction wood zones in the analysed trees overlapped entirely or partly with the determined periods of dendrogram divergence. These differently developed annual growths occurred most frequently in the same years for which the dendrochronological curve divergence was identified or with one-year latency, and, less often, two years later. These results demonstrate a definite delay in the process of developing reaction wood within the annual rings. This may be associated with the occasionally long process of tree's return to the upright position, from which it had been shifted due to ground movement. The results also indicate that reaction wood is not always associated with the eccentricity of annual growth.

The reactive trees (i.e. trees that exhibited deconcentric tree ring growth over a given time period and/or the reaction wood) are summarized on maps created for either decades or individual years (Fig. 4). As a consequence, it has been possi- ble to reconstruct landslide activity over the last 100 -year period. However, this landslide, as shown by both the oldest trees examined in this study and data from the literature, was active before this period. From the 1920s to 1940s, the upper part (near the concave scarp) and the middle part of the landslide were active. After 1951, movement was recorded over almost the entire area of the landslide body covered by the forest, from the scarp to its middle part. Movement of the bedrock in similar zones continued until the end of the century. A clear decrease in the number of reactive trees in the upper and especially in the head parts of the landslide is noted to have occurred since 2000 when a decrease in landslide activity took place. By comparing the maps, it can be seen that the middle part of the landslide was the most active segment from which motion was recorded over the entire study period. Generally, the highest activity was recorded in the 1980s and 1990s.

\section{ECCENTRICITY INDEX EVALUATION}

The eccentricity in millimetres, calculated for coniferous trees growing on the landslide, ranged from $-125.46 \mathrm{~mm}$ to $138.45 \mathrm{~mm}$, and from $-37.63 \mathrm{~mm}$ to $70.14 \mathrm{~mm}$ for the benchmarks. The eccentricity index calculated for the entire tree trunk varied from $-114.29 \%$ to $113.06 \%$ for trees growing on the landslide, and from $-16.88 \%$ to $33.34 \%$ for trees growing in a stable area.

Movement indicators were observed in 33 conifers from the Sawicki Landslide based on the formerly calculated thresholds. The oldest signal of the motion occurred in 1900. A total of 536 signals were dated; $265(49.4 \%)$ were related to the upslope eccentricity and $271(50.6 \%)$ to the downslope eccentricity. Index values for the benchmark trees growing on a stable surface oscillate around $0 \%$, rarely exceeding $100 \%$. Index values are high for trees growing on the landslide, which confirms that they grew on unstable ground. The maximum eccentricity index values are $2588.9 \%$ (landslide) and $339 \%$ (benchmarks) for the upslope eccentricity $-2200 \%$, and $-463.6 \%$ for the downslope eccentricity.

Variability of the number of dated signals related to gravitational mass movements for individual years in the entire period of 1900-2011 was analysed (Fig. 3B and Table 2). The greatest number of activity signals recorded in tree rings was seen in the years 1997, 1998 (14 specimens, about $42 \%$ of the analysed trees) and 1968 (13 specimens, about 39\% of the analysed trees). A large number of signals was also observed for 1975 , 1977, 1978, 1979 and 1988 (12 specimens, 36\% of the analysed trees) and 1983, 1984, 1985 and 1989 (11 specimens, $\sim 33 \%$ of trees).

\section{DISCUSSION}

Periods of gravitational ground movement, as determined using dendrochronological methods, were correlated with climatic data, such as precipitation records in the vicinity of the Sawicki landslide. The humid years were designated based on precipitation and temperature data from 1968-2011 obtained from the Polish Academy of Science Meteorological Field Station in Szymbark. The highest total precipitation, exceeding $1000 \mathrm{~mm}$, was recorded in Szymbark five times during that period, with the highest values in $1974(1164 \mathrm{~mm})$ and in 2010 $(1137 \mathrm{~mm})$. Only some of the years of strong tree reaction 


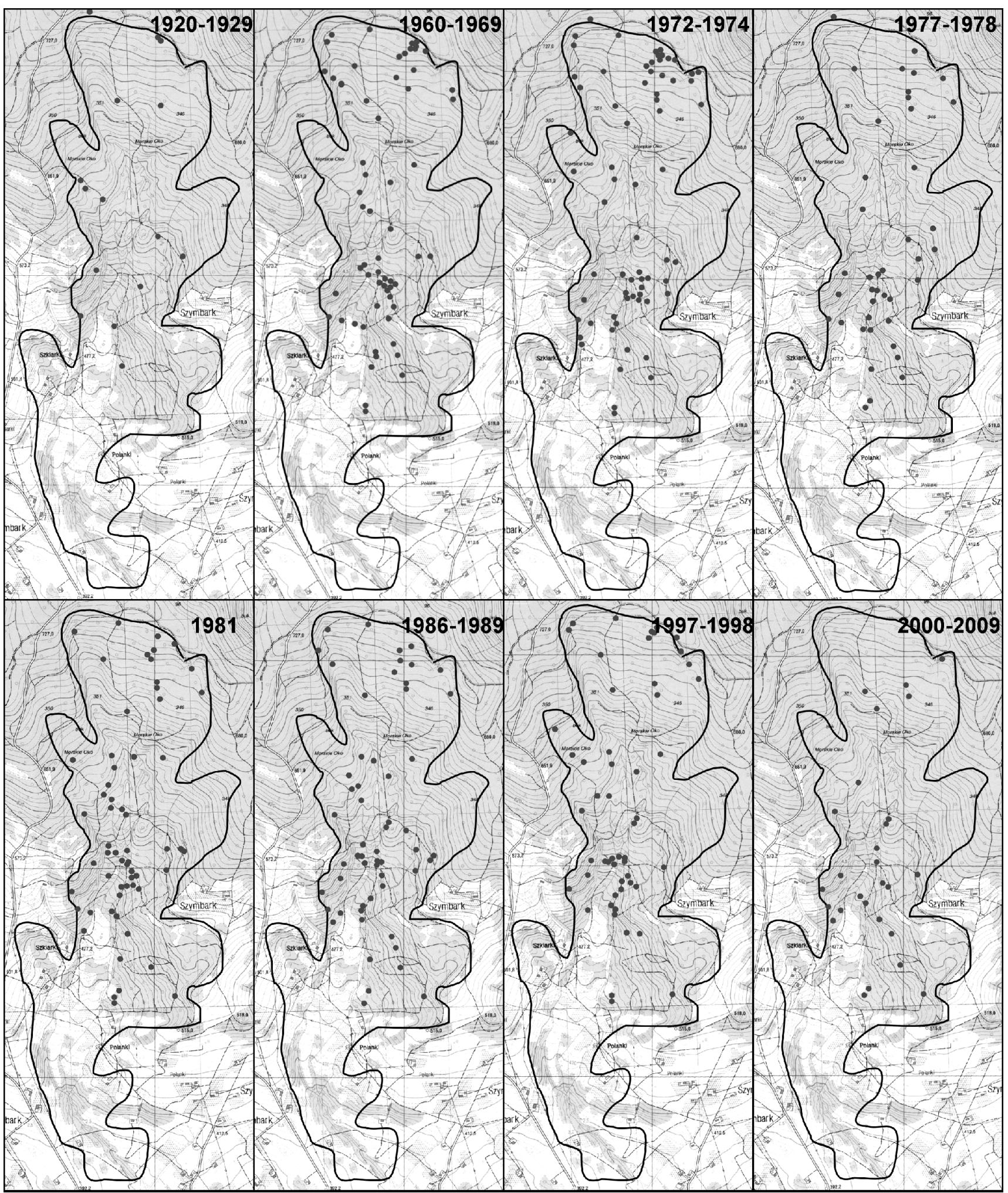

Fig. 4. Distribution of trees on the landslide area, showing the response to the ground movement

could be directly related to high rainfall years or those following high rainfall years in the vicinity of Szymbark. For instance, 1981 was characterized by a strong tree response that may have been connected with extreme total rainfalls recorded in 1980 , during which the total vegetation period rainfall amounted to $910.5 \mathrm{~mm}$. Although heavy rains caused flooding in 1997 in southern Poland, that year was only slightly more hu- mid than average. However, a clear response of trees from that year was noted, indicating intensification of gravitational movements of the ground. Our results demonstrate that the direct impact of landslide activity is reflected in trees almost immediately in years of high total rainfall (e.g., 1973, 1997, 1998), or with a delay of one year (e.g., 1971, 1981, 1986, 2011; Fig. 4 and Table 2). 
Table 2 that cause transformation of internal mechanical properties of rock massifs, such as, e.g., shear strength (Brunsden, 1979). Besides the sudden in-

Comparison of the years with the highest numbers of trees exhibiting diagnostic changes identified by the analysis of pairs of dendrochronological curves of opposite radii and by the eccentricity index method

\begin{tabular}{|c|c|c|}
\hline Decade & $\begin{array}{c}\text { Analysis of pairs of } \\
\text { dendrochronological curves }\end{array}$ & Eccentricity index \\
\hline $1950-1960$ & 1951 & $\mathbf{1 9 6 8}$ \\
\hline $1960-1970$ & 1961,1965 & $1975,1977,1978,1979$ \\
\hline $1970-1980$ & $\mathbf{1 9 7 1 , 1 9 7 3 , 1 9 7 7}$ & $\mathbf{1 9 9 7}$ \\
\hline $1980-1990$ & $\mathbf{1 9 8 1 , 1 9 8 6 , 1 9 8 8 , 1 9 8 9}$ & $1983,1984,1985,1988,1989$ \\
\hline $1990-2000$ & $1993,1997,1998$ & \\
\hline $2000-2011$ & $2000-2002$ & \\
\hline
\end{tabular}

The years with the highest number of diagnostic episodes for ground movement are in bold

In other cases, slope activity can be triggered under the influence of other factors, which are difficult to interpret based on climate data. If favourable, these factors may lead to the renewal of mass movement precipitation over a wider area, in and around the Beskid Niski and Beskid Sadecki Mountains, as occurred in 1897, 1906, 1934, 1955, 1958, 1970, 1973, 1983, 1997, 1999 and 2002. Also in this case, ground movement occurred only in some of the years, in 1973, 1997 (with a one-year delay) and 1970 (movement episode in 1971), as registered in annual growths.

In the following "humid" years (during which great precipitation was recorded) the ground gravitational displacements were reflected in tree rings (Table 2):

- 1980 was reflected with a one-year delay, very strongly in the analysis of pairs of dendrochronological curves, but less distinctly in the eccentricity index method,

- 1985 was reflected in the eccentricity index evaluation, and with a one-year delay in the analysis of pairs of dendrochronological curves

- 1970 was reflected with a delay of one year, very strongly in the analysis of the curves, less distinctly in the eccentricity index method

- 1974 was the year of record total rainfall, although it was reflected with a one-year delay only in the eccentricity index method,

-2001 was not reflected in any of the methods used.

Numerical modelling of the slope of Mt. Maślana Góra (Rączkowski and Zabuski, 2008) demonstrated that even a slight increase in rainfall could trigger movement in the upper part of the landslide, subsequently intensifying and covering wider parts of the landslide body. Our results seem to confirm that hypothesis - in humid and very humid years and in the immediately following ones, as displayed by the annual growths of trees growing on the entire surface of the landslide (e.g., 1981). However, the strong reaction of the tree rings in "dry" years occurring after equally dry ones (e.g., 1977), or in years with low total annual rainfall after the average ones, is puzzling.

The mass movement activity was usually associated with strong precipitation (e.g., Dikau et al., 1996; Turner and Schuster, 1996; Starkel, 1997). Nevertheless, formation of a landslide is associated with a drastic, abrupt change of factors crease in moisture of rocks, these factors include drying of bedrock and lowering of groundwater table. Abrupt drying can cause rapid shrinkage of the rock medium (mainly clays and silts, in which cracking occurs due to drying; Brunsden, 1979). The most conducive to the formation of mass movements is the successive spreading (expansion) and contraction of the substrate rocks as a result of changes in humidity such as intense precipitation, followed by extremely dry periods (Brunsden, 1979; Selby, 1993). Owing to the complex geological structure of the Sawicki Landslide bedrock (shales interbedded by sandstones), dehydration could have played an important role in the initiation of mass movements. It is also possible that landslide activity in dry periods could be related to a low-magnitude earthquake (see Wistuba et al., 2018) in the Beskid Niski Mts. (Guterch and Lewandowska-Marciniak, 2002).

\section{CONCLUSIONS}

An increase in the activity of particular parts of the landslide, registered in the annual increments of trees in periods of high rainfall, among others in 1934, 1970, 1972, 1980, 1997 and 2010 (often recorded in the annual increments one year later), seems unambiguous. However, dendrochronological signals indicate that the onset of ground movements also occurs in dry years (e.g., in 1977) or low-rainfall years, which implies a significant susceptibility of this specific slope-valley geosystem (Sawicki Landslide transforms the creek up-valley to its sources) to slide movements, even upon minor hydrological changes. Among the external factors currently discussed in the literature, initiation of the mass movements could also be related to quick drying of the ground, resulting in changes in rock strength parameters. Due to the occurrence of landslides in hydrologically active zones (spring areas, creek valley with minor tributaries), even a small amount of rainfall can result in disequilibration of the dynamic balance between landslide masses and the ground.

The dendrogeomorphological analysis, carried out with three independent methods (eccentricity of annual growth rings, eccentricity indices, and analysis of reaction wood), highlights their complementarity for the reconstruction of periods of ground transformation resulting from mass movements. Comparable results obtained using dendrogeomorphological analysis carried out for various tree species extend the possibilities of using dendrochronological methods for dating secondary gravitational movements.

Acknowledgements. The study was carried out as a part of statutory research of the Faculty of Geology, Geophysics and Environmental Protection, AGH - University of Science and Technology, grant No. 16.16.140.315. Special thanks are due to the Reviewers for substantive comments, which improved the quality of this article. 


\section{REFERENCES}

Alestalo, J., 1971. Dendrochronological interpretation of geomorphic processes. Fennia, 105: 1-140.

Alexandrowicz, S.W., 1996. Stages of increased mass movements in the Carpathians, during the Holocene. Kwartalnik $\mathrm{AGH}$, Geologia, 22: 223-262.

Baillie, M.G.L., 2008. Proposed re-dating of the European ice core chronology by seven years prior to the 7th century AD. Geophysical Research Letters, 35: doi: 10.1029/2008GL034755

Bekker, M.F., 2010. Tree ring and earthquakes. In: Tree Rings and Natural Hazards: a State-of-the-Art (eds. M. Stoffel, M. Bollschweiler, D.R. Butler and B.H. Luckman): 391-397. Springer, Heidelberg, New York.

Bober, L., 1984. Landslides in the Polish Flysch Carpathians, and their relation to geology of the region (in Polish with English summary). Biuletyn Państwowego Instytutu Geologicznego, 340: 115-158.

Bollschweiler, M., Stoffel, M., Vazqerez Selem, L., Palacios, D., 2009. Tree-rings reconstruction of past lahar activity at Popocatepetl volcano, Mexico. The Holocene, 20: 265-274.

Braam, R.R., Weiss, E.E.J., Burrough, P.A., 1987a. Spatial and temporal analysis of mass movement using dendrochronology. Catena, 14: 573-584.

Braam, R.R., Weiss, E.E.J., Burrough, P.A., 1987b. Dendrogeomorphological analysis of mass movement: a technical note on the research method. Catena, 14: 585-598.

Brunsden, D., 1979. Mass movements. In: Process in Geomorphology (eds. C. Embleton and J. Thornes): 130-186, Edvard Arnold., London.

Corominas, J., Moya, J., 1999. Reconstructing recent landslide activity in relation to rainfall in the Llobregat River basin, eastern Pyrenees, Spain. Geomorphology, 30: 79-93.

Dauksza, L., Gil, E., Kotarba, A., Słupik, J., Starkel, L., 1970. Investigation of the research station of the Institute of Geography of the Polish Academy of Sciences at Szymbark near Gorlice. Studia Geomorphologica Carpatho-Balcanica, 4: 121-141.

Dikau, R., Brunsden, D., Schrott, L., Ibsen, M.L., eds., 1996. Landslide recognition. Identification, Movement and Causes. J. Wiley et Sons.

Długosz, M., 2011. Landslide susceptibility in the Polish Carpathians. Prace Geograficzne, 230: 1-112.

Edvardsson, J., Linderson, H., Rundgren, M., Hammarlund, D., 2012. Holocene peatland development and hydrological variability inferred from bog-pine dendrochronology and peat stratigraphy - a case study from southern Sweden. Journal of Quaternary Science, 27: 553-563.

Fantucci, R., Sorriso-Valvo, M., 1999. Dendrogeomorphological analysis of a slope near Lago, Calabria (Italy). Geomorphology, 30: 165-174.

Gil, E., Gilot, E., Szczepanek, K., Kotarba, A., Starkel, L., 1974. An Early Holocene landslide in the Beskid Niski and its significance for palaeogeographical reconstructions. Studia Geomorphologica Carpatho-Balcanica, 8: 69-83.

Guterch, B., Lewandowiska-Marciniak, H., 2002. Seismicity and seismic hazard in Poland. Folia Quaternaria, 73: 85-99.

Jankowski, L., 2007. Chaotic complexes in Gorlice region (Polish Outer Carpathians) (in Polish with English summary). Biuletyn Państwowego Instytutu Geologicznego, 426: 27-52.

Jankowski, L., 2015. A new history of the evolution of the Carpathian orogeny - controversial point of view (in Polish with English summary). Prace Naukowe Instytutu Nafty i Gazu, Państwowego Instytutu Badawczego, 202: 1-154.

Jankowski, L., Margielewski, W., 2014. Structural control on the Outer Carpathians relief - a new approach (in Polish with English summary). Przegląd Geologiczny, 62: 29-35.

Kiszka, K., 2016. Dendrochronological study of the Sawicki landslide activity in the Beskid Niski Mts. (Polish Flysch Carpathians). Landform Analysis, 32: 9-26.
Kopciowski, R., Zimnal, Z., Chrząstowski, J., Jankowski, L., Szymakowska, F., 1997. Szczegółowa mapa geologiczna Polski 1: 50 000, arkusz 1037 Gorlice (in Polish). Państwowy Instytut Geologiczny - Państwowy Instytut Badawczy.

Kopciowski, R., Zimnal, Z., Chrząstowski, J., Jankowski, L., Szymakowska, F., 2014. Objaśnienia do szczegółowej mapy geologicznej Polski 1: 50 000, arkusz Gorlice (1037) (in Polish). Państwowy Instytut Geologiczny - Państwowy Instytut Badawczy.

Kotarba, A., 1986. Rola osuwisk w modelowaniu rzeźby beskidzkiej i pogórskiej (in Polish). Przegląd Geograficzny, 58: 119-129.

Krawczyk, A., Krąiec, M., 1995. Dendrochronologiczna baza danych (in Polish). Materiały II Krajowej Konferencji: Komputerowe Wspomaganie Badań Naukowych, Wrocławskie Towarzystwo Naukowe, Wrocław: 247-252.

Krapiec, M., Margielewski, W., 1991. Use of dendrogeomorphological analysis in age determination of surface mass-movements (in Polish with English summary). Kwartalnik AGH Geologia, 17: 67-81.

Krąpiec, M., Margielewski, W., 2000. Dendrogeomorphological analysis of mass movements in the Polish Flysch Carpathians (in Polish with English summary). Kwartalnik AGH Geologia, 26: 141-171.

Krąpiec, M., Rączkowski, W., 2005. Dendrogeomorfologiczny monitoring ruchów osuwiskowych na obszarze Beskidu Niskiego (in Polish). In: Współczesna ewolucja rzeźby Polski (eds. A. Kotarba, K. Krzemień and J. Święchowicz): 231-240. Wydawnictwo Uniwersytetu Jagiellońskiego, Kraków.

Krąpiec, M., Rączkowski, W., Danek, M., Kłusek, M., Gil, E., Zabuski, L., 2008. Monitoring dendrogeomorfologiczny osuwisk w Beskidzie Niskim (in Polish). Prace Komisji Paleogeografii Czwartorzędu PAU, 6: 173-184.

Krapiec, M., Margielewski, W., Korzeń, K., Szychowska-Krąpiec, E., Nalepka, D., Łajczak, A., 2016. Late Holocene palaeoclimate variability: the significance of bog pine dendrochronology related to peat stratigraphy. The Puścizna Wielka raised bog case study (Orawa-Nowy Targ Basin, Polish Inner Carpathians). Quaternary Science Reviews, 148: 192-208.

Łajczak, A., Margielewski, W., Rączkowska, Z., Święchowicz, J., 2014. Contemporary geomorphic processes in the Polish Carpathians under changing human impact. Episodes, 37: 21-32.

Malik, I., Wistuba, M., 2012. Dendrochronological methods for reconstructing mass movements - an example of landslide activity analysis using tree-ring eccentricity. Geochronometria, 39: $180-196$.

Malik, I., Danek, M., Marchwińska-Wyrwał, E., Danek, T., Wistuba, M., Krąpiec, M., 2012. Scots Pine (Pinus sylvestris L.) Growth suppression and adverse effects on human health due to air pollution in the Upper Silesian Industrial District (USID), Southern Poland. Water Air and Soil Pollution, 223: 3345-3364.

Margielewski, W., 2006. Records of the Late Glacial-Holocene palaeoenvironmental changes in landslide forms and deposits of the Beskid Makowski and Beskid Wyspowy Mts. area (Polish Outer Carpathians). Folia Quaternaria, 76: 1-149.

Margielewski, W., 2018. Landslides fens as a sensitive indicator of the palaeoenvironmental changes since the Late Glacial; Polish Western Carpathians case study. Radiocarbon, 60: 1199-1213.

Margielewski, W., Michczyński, A., Obidowicz, A., 2010. Records of the Middle - and Late Holocene palaeoenvironmental changes in the Pcim - Sucha landslide peat bogs (Beskid Makowski Mts., Polish Outer Carpathians). Geochronometria, 35: 11-23.

McAuliffe, J.R.,, Scuderi, L.A., McFAdden, L.D., 2006. Tree-ring record of hillslope erosion and valley floor dynamics: landscape responses to climatic variation during the last $400 \mathrm{yr}$ in the Colorado Plateau, northeastern Arizona. Global and Planetary Change, 50: 184-201.

Mrozek, T., 2013. Landslide hazard and risk for a case-study of Szymbark region (Beskid Niski Mts.) (in Polish with English 
summary). Prace Państwowego Instytutu Geologicznego, 199: $1-40$.

Nawrocka, N., 2013. Dendrogeomorphological analysis of trees of various species from the L. Sawicki's landslide area, Szymbark, Beskid Niski (Low) Mts, Flysch Carpathians (in Polish with English summary). Folia Quaternaria, 81: 175-188.

Oleksyn, J., 1988. High growth of different European Scots pine provenances in a heavy polluted and control environment. Environmental Pollution, 55: 289-299.

Pazdur, A., Korput, S., Fogtman, M., Szczepanek, M., Halas, S., Krapiec, M., Szychowska-Krapiec, E., 2005. Carbon-13 in alpha-cellulose of oak latewood (Jędrzejów, Southern Poland) during the Maunder Minimum. Geological Quarterly, 49 (2): 165-171.

Rączkowski, W., 2007a. Landslide hazard in the Polish Flysch Carphatians. Studia Geomorphologica Carpato-Balcanica, 41: 61-75.

Rączkowski, W., 2007b. System Ochrony Przeciwosuwiskowej Karta Rejestracji Osuwiska 1205042-2 (manuscript) (in Polish). Państwowy Instytut Geologiczny - Państwowy Instytut Badawczy.

Raczkowski, W., Zabuski, L., 2008. Numerical modeling of the landslide slope deformation - Maślana Góra in Szymbark near Gorlice (in Polish with English summary). Kwartalnik AGH Geologia, 34: 733-742.

Sawicki, L., 1917. Osuwiska ziemne w Szymbarku i inne zsuwy powstałe w 1913 r w Galicji Zachodniej (in Polish). Rozprawy Wydziału Matematyczno-Przyrodniczego Akademii Umiejętności w Krakowie, 56A: 227-313.

Selby, M.J., 1993. Hillslope Materials and Processes. Oxford University Press, Oxford.

Shroder, J.F., 1980. Dendrogeomorphology: review and new techniques of tree-ring dating. Progress in Physical Geography, 4: 161-188.

Starkel, L., 1960. The development of the Flysch Carpathians relief during the Holocene (in Polish with English summary). Prace Geograficzne IG PAN, 22: 1-239.

Starkel, L., 1997. Mass movement during the Holocene: Carpathian example and the European perspective. Palaeoclimate Research, 19: 385-400.

Silhan, K., Stoffel, M., 2015. Impacts of age-dependent tree sensitivity and dating approaches on dendrogeomorphic time-series of landslides. Geomorphology, 236: 34-43.

Stefanini, M.C., 2004. Spatio-temporal analysis of a complex landslide in the Northern Apeninnes (Italy) by means of dendrochronology. Geomorphology, 63: 191-202.
StGeorge, S., Nielsen, E., 2002. Hydroclimatic change in southwestern Manitoba since A.D.1409 inferred from tree rings. Quaternary Science Reviews, 58: 103-111.

Stoffel, M., Wilford, D.J., 2012. Hydrogeomorphic processes and vegetation: disturbance, process histories, dependencies and interaction. Earth Surface Processes and Landforms, 37: 9-22.

Stoffel, M., Butler, D.R., Corona, C., 2013. Mass movements and tree rings: a guide to dendrogeomorphic field sampling and dating. Geomorphology, 200: 106-120.

Stoffel, M., Casteller, A., Luckman, B.H., Villalba, R., 2012. Spatiotemporal analysis of channel wall erosion in ephemeral torrents using tree roots - an example from the Patagonian Andes. Geology, 40: 247-250.

Szychowska-Krapiec, E., 2010. Long-term chronologies of pine (Pinus sylvestris L.) and fir (Abies alba Mill.) from the Małopolska region and their palaeoclimatic interpretation. Folia Quaternaria, 79: 1-120.

Świdziński, H., 1973. The geological structure and the oil-bearing capacity of the region Szymbark near Gorlice (in Polish with English summary). Prace Geologiczne, 80: 11-61.

Turner, A.K., Schuster, R.L. eds., 1996. Landslides: Investigation and Mitigation. Transportation Research Board, National Academy of Sciences, vol. 247: 391-424. Special Report, Washington, D.C.

Walanus, A., 2005. Program Quercus, Instrukcja obsługi (in Polish). Kraków.

Wistuba, M., Malik, I., 2011. Indeks dekoncentryczności przyrostów rocznych drzew - narzędzie do identyfikacji współczesnych ruchów osuwiskowych. Czasopismo Geograficzne, 82: 401-421.

Wistuba, M., Malik, I., Gartner, H., Kojs, P., Owczarek, P., 2013. Application of eccentric growth of tree-rings as a tool for landslide analyses (an example of Picea abies Karst. in the Carpathian and Sudeten Mountains - Central Europe). Catena, 111: 41-55.

Wistuba, M., Malik, I., Krzemień, K., Gorczyca, E., Sobucki, M., Wrońska-Wałach, D., Gawior, D., 2018. Can low-magnitude earthquakes act as a triggering factor for landslide activity? Examples from the Western Carpathian Mts, Poland. Catena, 171: 359-375.

Wójcik, A., Mrozek, T., Granoszewski, W., 2006. Lithological conditioning of landslides and climatic changes with examples from the Beskidy Mts., Western Carpathians, Poland. Geografia Fisica e Dinamica Quaternaria, 29: 197-209.

Zabuski, L., Wójcik, A., Gil, E., Mrozek, T., Raczkowski, W., 2009. Landslide process in a flysch massif - case study of the Kawiory landslide, Beskid Niski Mts. (Carpathians, Poland). Geological Quarterly, 53 (3): 317-332. 